\title{
Effect of Post-harvest Treatments and Packaging on Spinach Beet (Beta vulgaris var bengalensis Hort.) under Ambient Condition
}

\author{
B.V.G. Prasad ${ }^{1 *}$, S. Chakravorty ${ }^{1}$, P. Ganagadhara Rao $^{2}$ and P. Deb ${ }^{1}$ \\ ${ }^{1}$ Post-Harvest Laboratory, Department of Horticulture and Post-Harvest Technology, \\ Institute of Agriculture (PSB), Sriniketan, Visva-Bharati (A Central University), \\ West Bengal - 731236, India \\ ${ }^{2}$ DR. Y. S. R. Horticultural University, India \\ *Corresponding author
}

\section{A B S T R A C T}

The present experiment was conducted in postharvest laboratory of Department of Horticulture \& Postharvest Technology, Institute of Agriculture to find out the ideal

\section{Keywords}

Spinach beet, Packaging, Ascorbic acid, Benzoic acid and shelf life

Article Info

Accepted:

07 October 2018

Available Online:

10 November 2018 chemical treatment and packaging to increase the postharvest storage life of spinach beet under ambient storage condition. After harvesting the spinach beet plants were treated with different chemicals $(0.3 \%$ ascorbic acid, $0.3 \%$ citric acid, $0.5 \%$ common salt, $0.5 \%$ sugar, $0.005 \%$ benzoic acid and distill water) and packed in various packing materials (perforated LDPE packing, news paper packaging and without packing). The treatments consisted of chemical treatments and packing. The experiment was laid out in completely Randomized Design (CRD) in factorial manner. Results from the experiment reviled that highest number of days (6.5) to $50 \%$ colour change, $50 \%$ rotting and lowest respiration rate $(52.28$ mL.kg $\left.{ }^{-1} \cdot \mathrm{hr}^{-1}\right)$ was observed in $\mathrm{T}_{3} \mathrm{P}_{3}(0.005 \%$ benzoic acid +LDPE packing $)$. Lowest physiological loss in weight $(78.80 \mathrm{~g} / 100 \mathrm{~g})$, ethylene production $\left(8.41 \mathrm{nl} \cdot \mathrm{g}^{-1} \cdot \mathrm{hr}^{-1}\right)$, highest dry matter content $(22.96 \mathrm{~g} / 100 \mathrm{~g})$, which led to increase in shelf life up to 5days in $\mathrm{T}_{1} \mathrm{P}_{3}$ (0.3\% ascorbic acid + LDPE packing).

\section{Introduction}

Spinach beet belongs to the family chenopodiaceae is one of the most important leafy vegetables of tropical and sub-tropical region and is grown widely in India. It has the potential source of Vitamin A, C and contains appreciable amount of protein, calcium, iron and low oxalic acid. Post-harvest losses of leafy vegetables is one of the important production problem estimated over $30 \%$ which are generally caused by poor handling and storage conditions (Nyaura et al., 2005).
Post-harvest losses in spinach beet is about $25 \%$ which is mainly due its high perishability due to high respiration rate and rapid deterioration after harvest, poor handling after harvesting, improper packaging and lack of improved storage techniques etc. Ascorbic acid, citric acid and benzoic acids are the most widely used post-harvest chemicals to enhance the storage life and delaying in colour change of harvested produce inhibition of oxidation from cut leafy vegetables and improvement of shelf life in leafy vegetables, respectively (Whitaker, and Lee, 1995). Natural 
preservatives like common salt, sugar are also potential and cheap sources to increase the postharvest shelf life and quality standards through exosmasis of water which inhibit the growth of microorganisms and endogenous sugar levels increases shelf life. Rapid loss of water from leafy vegetables is a serious problem and packing with suitable material is advocated. Appropriate packaging helps to maintain high humidity, inhibit wilting and reduce weight loss (Brandl and Mandrell, 2002). Therefore, selection of suitable packing material is an important issue apart from its easy availability. Leafy vegetables contain high respiration rate and knowledge on respiration rate and ethylene production will help to understand post-harvest behavior of leafy vegetables under different chemical treatments and packing condition, thereby providing information for the selection of appropriate chemical treatment and packaging for the leafy vegetable. Considering the above views, the present experiment was conducted to find out the best chemical treatment and packaging condition to enhance spinach beet storage life.

\section{Materials and Methods}

Present experiment was conducted in PostHarvest laboratory of Department of Horticulture and Post-Harvest Technology, Institute of Agriculture, Visva-Bharati University. Spinach beet plants were harvested at commercial maturity stage from properly managed field. After washing with water, plants were treated separately for 15 minutes with chemicals viz. Ascorbic acid- $0.3 \%$ (T1), Citric acid- $0.3 \%\left(\mathrm{~T}_{2}\right)$, Benzoic acid- $0.005 \%$ $\left(\mathrm{T}_{3}\right)$, Common salt $(\mathrm{NaCl})-0.5 \%\left(\mathrm{~T}_{4}\right)$, Sugar$0.5 \%\left(\mathrm{~T}_{5}\right)$ and Distil water- $\left(\mathrm{T}_{6}\right)$ and placed on blotting paper to remove surface moisture. About $100 \mathrm{~g}$ of spinach beet plants were packed in each type of packing material viz., without packing material (as control) $\left(\mathrm{P}_{1}\right)$, Low Density Poly Ethylene (LDPE) pack (100 gauge, having $0.1 \%$ perforation $\left(\mathrm{P}_{2}\right)$ and News print $(0.1 \%$ perforations $)\left(\mathrm{P}_{3}\right)$. The experiment was designed in FCRD and each treatment was replicated thrice. The treatment combinations consisted of chemical treatments and packing.

Ethylene and respiration rate were measured by gas chromatography. It is a static system, the commodity is enclosed in an airtight container and can be accurately detected by using ethylene analyzer (CI-900, CID BioScience, Inc.). The experiment was laid out in completely Randomized Design (CRD) with eighteen treatments and three replications. Observations recorded on Physiological loss in Weight (PLW), dry matter content (\%), shelf life (days), number of days to colour change, days to rotting initiation and 50\% rotting. Ethylene production rate $\left(\mathrm{nl} . \mathrm{g}^{-1} \cdot \mathrm{hr}^{-1}\right)$, respiration rate $\left(\mathrm{ml}^{\mathrm{kg}} \mathrm{kg}^{-1} \cdot \mathrm{hr}^{-1}\right)$, oxygen consumption rate $\left(\mathrm{ml} . \mathrm{kg}^{-1} \cdot \mathrm{hr}^{-1}\right)$, temperature $\left({ }^{0} \mathrm{C}\right)$, relative humidity $(\%)$ and vital heat (Kcal.Ton ${ }^{-1} .24 \mathrm{hrs}$.) was observed at initial and final consumption stage (shelf life).

Data were statistically analyzed using XLSTAT (US, NY, 2016 version) software to determine the mean difference between treatments. The method of Duncan Multiple Range Test (DMRT) was used to differentiate treatment means at $p \leq 0.05$. Regression analysis was conducted to find out relationships between shelf life and ethylene, respiration rate and temperature.

\section{Results and Discussion}

Irrespective of chemical treatments significant reduction in physiological loss in weight (PLW) was observed in LDPE, followed by newsprint packing. The maximum PLW (63.47, 52.07 and $20.73 \mathrm{~g} / 100 \mathrm{~g}$ respectively) was recorded in $\mathrm{T}_{6} \mathrm{P}_{1}$ (distilled water + no packing) during all the stages of observations (i.e. 2,4 and $6^{\text {th }}$ day). The minimum values 
(98.93, 83.60 and $78.80 \mathrm{~g} / 100 \mathrm{~g}$, respectively) in this regard was observed in $\mathrm{T}_{1} \mathrm{P}_{3}(0.3 \%$ ascorbic acid + LDPE packing) during the said stages (Fig. 1). The reduction in PLW of spinach beet under $\mathrm{T}_{1} \mathrm{P}_{3}$ might be due to development of high relative humid condition in LDPE led to reduction in respiration rate of spinach beet due to inhibitory activity of oxidases such as polyphenol oxidase, ascorbic acid oxidase and beet glycol acid oxidase (Burton, 1978), further high PLW under ambient storage of French bean was also observed (Prasad et al., 2014). The maximum drying percentage $(22.96 \%)$ was observed in treatment $\mathrm{T}_{1} \mathrm{P}_{3}(0.3 \%$ ascorbic acid + LDPE packing) and minimum (8.90\%) in this regard in $\mathrm{T}_{6} \mathrm{P}_{1}$ (distilled water + no packing) (Table.1). Retention of high dry matter with the use of any packaging material might be due to comparatively lower respiration rate. Use of ascorbic acid produced the maximum benefit probably by decreasing the degradation of reserved food by dint of its antioxidant activity.

Among various treatment combinations highest shelf life (5days) was observed where the palak plants treated with $0.3 \%$ ascorbic acid and stored under LDPE packaging condition the lowest shelf life observed in distill water treatment with no packaging condition. The highest shelf life (5days) was observed in the treatment $\mathrm{T}_{1} \mathrm{P}_{3}(0.3 \%$ ascorbic acid + LDPE packing) and also in $\mathrm{T}_{3} \mathrm{P}_{3}$ (0.005\% Benzoic acid + LDPE packing). The lowest shelf life (2.5days) was observed in $\mathrm{T}_{4} \mathrm{P}_{1}(0.5 \%$ common salt + no packing) and $\mathrm{T}_{6} \mathrm{P}_{1}$ (distilled water + no packing) (Table.1). Among the chemicals used in the experiment, $0.3 \%$ ascorbic acid and $0.005 \%$ benzoic acid both under LDPE condition increased the shelf life of spinach beet. This might be due to retention of more humidity in LDPE which helped to reduce the rate of respiration and thus increased the shelf life of spinach beet. Benzyl adenine being a cytokinin derivative and ascorbic acid having antioxidant properties, which might have delayed senescence, decreased respiration and thus helped in retention of chlorophyll content in leafy vegetables (Majeski and Brasley, 1968).

Days taken to $50 \%$ colour change of the leaves were remarkably delayed under LDPE packing and it was accentuated under no packing condition. The maximum number of days to $50 \%$ colour change (6.5 days) was recorded in $\mathrm{T}_{3} \mathrm{P}_{3}(0.005 \%$ Benzoic acid and LDPE packing) (Table.1). The lowest value (3.0 days) was recorded in $\mathrm{T}_{6} \mathrm{P}_{1}$ (distilled water and no packing) and T4P1 $(0.5 \%$ common salt and no packing) in this regard. Minimum number of days to $50 \%$ colour change as observed with $0.5 \%$ common salt and no packing might be due to loss of water through exosmosis due to presence of salt and increased transpiration from leaf tissue.

Highest number of days to $50 \%$ rotting (7days) of spinach beet leaves was found in $\mathrm{T}_{3} \mathrm{P}_{1}(0.005 \%$ Benzoic acid and no packaging condition) and it was closely followed with $\mathrm{T}_{1} \mathrm{P}_{1}$ and $\mathrm{T}_{1} \mathrm{P}_{10}$ (6.5 days). The minimum value (4 days) observed in $\mathrm{T}_{6} \mathrm{P}_{3}$ (distilled water and LDPE packaging), The delay in days to $50 \%$ rotting as observed in the treatment $\mathrm{T}_{3} \mathrm{P}_{1}$ (0.005\% Benzoic acid and no packaging condition $)$ and $\mathrm{T}_{4} \mathrm{P}_{1}(0.5 \%$ common salt along and no packaging condition) might be due to action of Benzoic acid for reduction in the respiration rate of harvested produce and prevention of microbial decomposition due to presence of common salt, respectively. Moreover, increased moisture in the micro environment of LDPE packaging might have become congenial for early initiation 50\% rotting. The marginal improvement in delay in days to $50 \%$ rotting under news print packing over LDPE packaging might have capillary action of news paper packaging to absorb moisture evolved through transpiration and respiration. 
Table.1 Effect of Postharvest treatments and Packaging on Spinach beet under ambient condition

\begin{tabular}{|c|c|c|c|c|c|c|c|}
\hline Treatment & Chemical & Packaging & $\begin{array}{l}\text { Drying } \\
\text { percentage } \\
(\%)\end{array}$ & $\begin{array}{l}\text { Shelf } \\
\text { life } \\
\text { (Days) }\end{array}$ & $\begin{array}{l}\text { Days to } \\
50 \% \text { colour } \\
\text { change }\end{array}$ & $\begin{array}{l}\text { Days to } \\
50 \% \\
\text { rotting }\end{array}$ & $\begin{array}{l}\text { Ascorbic } \\
\text { acid } \\
(\mathrm{mg} / \mathrm{g})\end{array}$ \\
\hline $\mathrm{T}_{1} \mathrm{P}_{1}$ & $0.3 \%$ ascorbic acid & No packing & 9.66 & 3 & 3.5 & 6.5 & 23.00 \\
\hline $\mathrm{T}_{1} \mathrm{P}_{2}$ & $0.3 \%$ ascorbic acid & News print & 15.98 & 4 & 5.5 & 5.5 & 25.00 \\
\hline $\mathrm{T}_{1} \mathrm{P}_{3}$ & $0.3 \%$ ascorbic acid & LDPE Packing & 22.96 & 5 & 6.0 & 6 & 26.80 \\
\hline $\mathrm{T}_{2} \mathrm{P}_{1}$ & $0.3 \%$ citric acid & No packing & 10.62 & 3.5 & 4 & 6 & 23.95 \\
\hline $\mathrm{T}_{2} \mathrm{P}_{2}$ & $0.3 \%$ citric acid & News print & 14.38 & 4 & 5 & 5 & 24.88 \\
\hline $\mathrm{T}_{2} \mathrm{P}_{3}$ & $0.3 \%$ citric acid & LDPE Packing & 19.93 & 4.5 & 5.5 & 5.5 & 25.00 \\
\hline $\mathrm{T}_{3} \mathrm{P}_{1}$ & $0.005 \%$ Benzoic acid & No packing & 9.65 & 3 & 4 & 7 & 22.95 \\
\hline $\mathrm{T}_{3} \mathrm{P}_{2}$ & $0.005 \%$ Benzoic acid & News print & 16.50 & 4.5 & 5.5 & 5 & 23.55 \\
\hline $\mathrm{T}_{3} \mathrm{P}_{3}$ & 0.005\%Benzoic acid & LDPE Packing & 20.16 & 5 & 6.5 & 5.5 & 23.17 \\
\hline $\mathrm{T}_{4} \mathrm{P}_{1}$ & $0.5 \%$ Common salt & No packing & 9.76 & 2.5 & 3 & 6.5 & 22.12 \\
\hline $\mathrm{T}_{4} \mathrm{P}_{2}$ & $0.5 \%$ Common salt & News print & 13.13 & 3 & 3.5 & 5 & 23.18 \\
\hline $\mathrm{T}_{4} \mathrm{P}_{3}$ & $0.5 \%$ Common salt & LDPE Packing & 16.08 & 3.5 & 4.5 & 4.5 & 23.89 \\
\hline $\mathrm{T}_{5} \mathrm{P}_{1}$ & $0.5 \%$ Sugar & No packing & 9.95 & 3 & 4 & 5.5 & 23.01 \\
\hline $\mathrm{T}_{5} \mathrm{P}_{2}$ & $0.5 \%$ Sugar & News print & 14.88 & 3.5 & 4.5 & 4.5 & 23.85 \\
\hline $\mathrm{T}_{5} \mathrm{P}_{3}$ & $0.5 \%$ Sugar & LDPE Packing & 16.76 & 4 & 5 & 5.5 & 24.00 \\
\hline $\mathrm{T}_{6} \mathrm{P}_{1}$ & Distilled water & No packing & 8.90 & 2.5 & 3 & 5 & 22.00 \\
\hline $\mathrm{T}_{6} \mathrm{P}_{2}$ & Distilled water & News print & 14.45 & 3 & 4 & 4.5 & 23.50 \\
\hline $\mathrm{T}_{6} \mathrm{P}_{3}$ & Distilled water & LDPE Packing & 14.41 & 4 & 5 & 4 & 23.00 \\
\hline SE.m $( \pm)$ & & & 0.89 & 0.66 & 0.57 & 0.41 & 0.77 \\
\hline CD-5\% & & & 2.76 & 1.94 & 1.65 & 1.30 & 2.26 \\
\hline
\end{tabular}


Table.2 Effect of Postharvest treatments and Packaging on ethylene production and respiration rate Spinach beet under ambient condition

\begin{tabular}{|c|c|c|c|c|c|c|c|}
\hline Treatment & Chemical & Packaging & $\begin{array}{c}\text { Ethylene } \\
\left(\text { (nL }^{-1} \cdot \mathrm{g}^{-1} \text {. }\right. \\
\text { hr.) }\end{array}$ & $\begin{array}{l}\text { Carbon } \\
\text { di oxide } \\
(\mathbf{m l} .\end{array}$ & $\begin{array}{l}\text { Oxygen } \\
(\mathrm{ml} . \\
\left.\mathbf{K g}^{1} \cdot \mathbf{h r}^{-1}\right)\end{array}$ & $\begin{array}{l}\text { Temperature } \\
\left({ }^{0} \mathrm{C}\right)\end{array}$ & $\begin{array}{l}\text { Vital heat } \\
\text { (Kcal }^{-1} \text {. } \\
\text { Ton. }^{-1} .24 \\
\text { hrs) }\end{array}$ \\
\hline
\end{tabular}

\begin{tabular}{|c|c|c|c|c|c|c|c|}
\hline $\mathrm{T}_{1} \mathrm{P}_{1}$ & $0.3 \%$ ascorbic acid & No packing & 38.33 & 100.43 & 72.267 & 34.35 & 6179.44 \\
\hline $\mathrm{T}_{1} \mathrm{P}_{2}$ & $0.3 \%$ ascorbic acid & News print & 13.85 & 72.27 & 52.45 & 34.93 & 4415.28 \\
\hline $\mathrm{T}_{1} \mathrm{P}_{3}$ & $0.3 \%$ ascorbic acid & $\begin{array}{l}\text { LDPE } \\
\text { Packing }\end{array}$ & 8.41 & 52.28 & 38.70 & 34.67 & 3314.15 \\
\hline $\mathrm{T}_{2} \mathrm{P}_{1}$ & $0.3 \%$ citric acid & No packing & 25.16 & 81.21 & 59.13 & 31.70 & 4970.18 \\
\hline $\mathrm{T}_{2} \mathrm{P}_{2}$ & $0.3 \%$ citric acid & News print & 20.51 & 68.13 & 49.63 & 32.50 & 4190.15 \\
\hline $\mathrm{T}_{2} \mathrm{P}_{3}$ & $0.3 \%$ citric acid & $\begin{array}{l}\text { LDPE } \\
\text { Packing }\end{array}$ & 9.36 & 56.91 & 41.44 & 33.45 & 3482.60 \\
\hline $\mathrm{T}_{3} \mathrm{P}_{1}$ & $\begin{array}{l}0.005 \% \text { Benzoic } \\
\text { acid }\end{array}$ & No packing & 39.40 & 99.90 & 72.62 & 29.58 & 6113.56 \\
\hline $\mathrm{T}_{3} \mathrm{P}_{2}$ & $\begin{array}{l}0.005 \% \text { Benzoic } \\
\text { acid }\end{array}$ & News print & 11.86 & 65.58 & 40.63 & 30.56 & 3422.40 \\
\hline $\mathrm{T}_{3} \mathrm{P}_{3}$ & $\begin{array}{l}0.005 \% \text { Benzoic } \\
\text { acid }\end{array}$ & $\begin{array}{l}\text { LDPE } \\
\text { Packing }\end{array}$ & 9.15 & 55.46 & 47.49 & 28.29 & 4013.43 \\
\hline $\mathrm{T}_{4} \mathrm{P}_{1}$ & $0.5 \%$ Common salt & No packing & 50.03 & 105.63 & 76.76 & 35.18 & 6464.45 \\
\hline $\mathrm{T}_{4} \mathrm{P}_{2}$ & $0.5 \%$ Common salt & News print & 11.54 & 93.28 & 67.75 & 35.47 & 5708.47 \\
\hline $\mathrm{T}_{4} \mathrm{P}_{3}$ & $0.5 \%$ Common salt & $\begin{array}{l}\text { LDPE } \\
\text { Packing }\end{array}$ & 29.84 & 79.88 & 58.29 & 36.34 & 4884.89 \\
\hline $\mathrm{T}_{5} \mathrm{P}_{1}$ & $0.5 \%$ Sugar & No packing & 13.68 & 95.82 & 69.36 & 35.70 & 5864.18 \\
\hline $\mathrm{T}_{5} \mathrm{P}_{2}$ & $0.5 \%$ Sugar & News print & 22.72 & 77.27 & 56.44 & 35.80 & 4728.57 \\
\hline $\mathrm{T}_{5} \mathrm{P}_{3}$ & $0.5 \%$ Sugar & $\begin{array}{l}\text { LDPE } \\
\text { Packing }\end{array}$ & 15.36 & 78.52 & 57.37 & 35.93 & 4805.33 \\
\hline $\mathrm{T}_{6} \mathrm{P}_{1}$ & Distilled water & No packing & 44.53 & 110.34 & 80.20 & 35.11 & 6766.88 \\
\hline $\mathrm{T}_{6} \mathrm{P}_{2}$ & Distilled water & News print & 32.60 & 88.53 & 64.61 & 36.28 & 5418.20 \\
\hline $\mathrm{T}_{6} \mathrm{P}_{3}$ & Distilled water & $\begin{array}{l}\text { LDPE } \\
\text { Packing }\end{array}$ & 19.33 & 76.14 & 55.41 & 36.00 & 4659.66 \\
\hline \multicolumn{3}{|c|}{ SE.m $( \pm)$} & 0.88 & 1.26 & 1.20 & 0.99 & 48.66 \\
\hline \multicolumn{3}{|c|}{ CD-5\% } & 2.53 & 3.63 & 1.70 & 2.85 & 139.58 \\
\hline
\end{tabular}


Fig.1 Effect of postharvest treatments and packaging on Physiological Loss in Weight (PLW) (g) in spinach beet under ambient condition

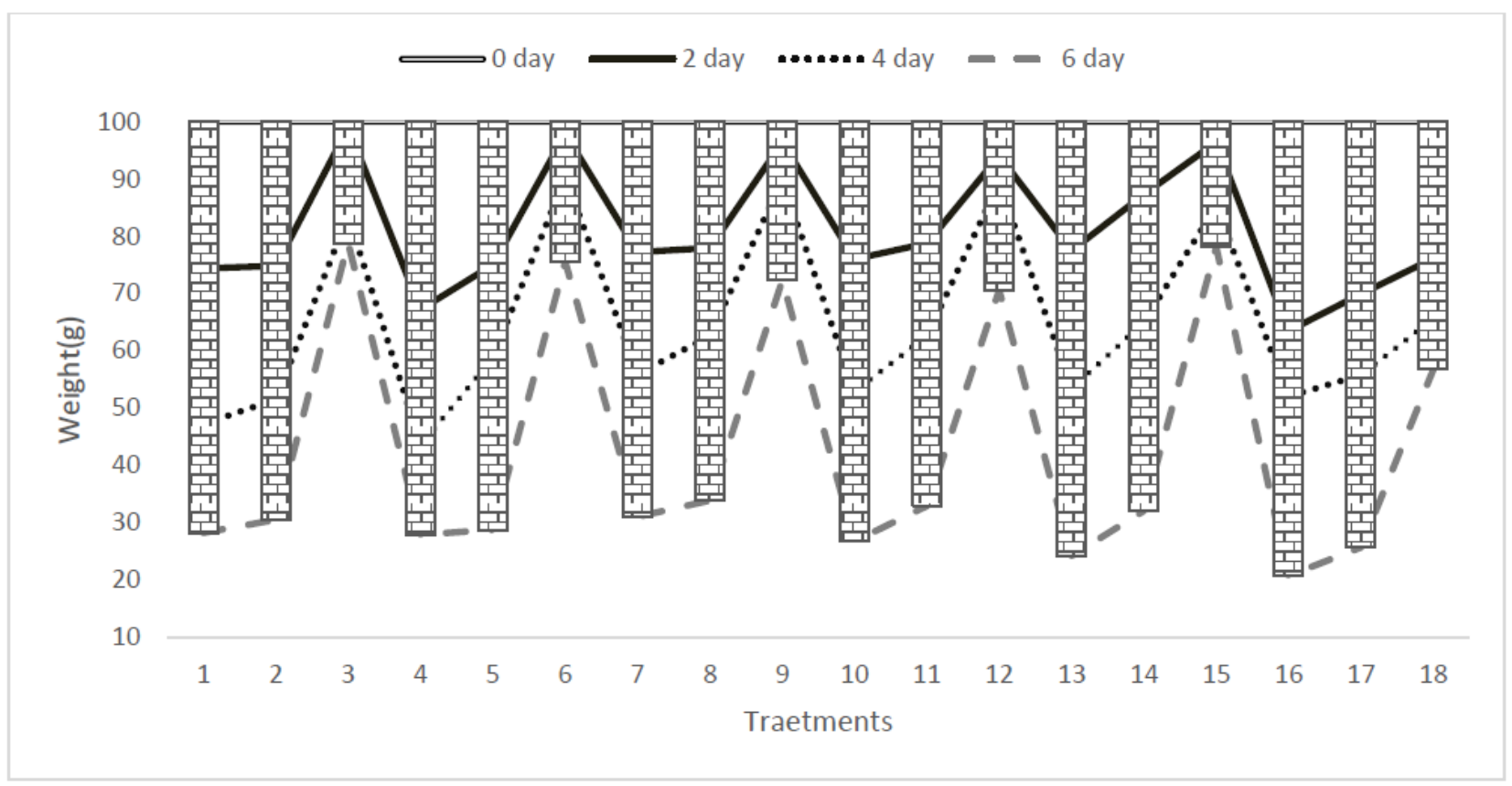

Fig.2 Effect of postharvest treatments and packaging on chlorophyll content (mg/g) and TSS $\left({ }^{0} \mathrm{Bx}\right)$ of spinach beet under ambient condition

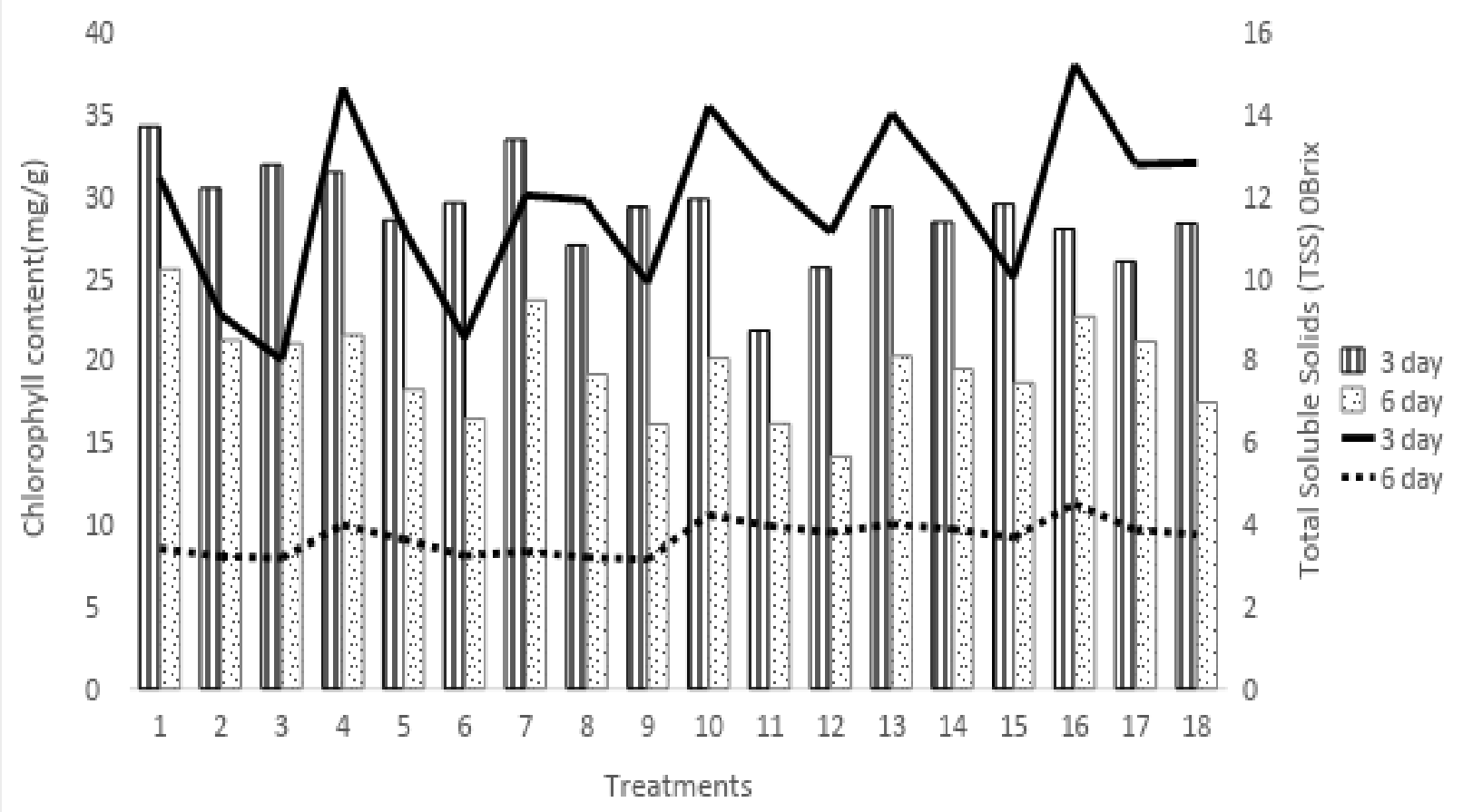


Fig.3 Mean values of ethylene $\left(\mathrm{nl} . \mathrm{g}^{-1} \cdot \mathrm{hr}^{-1}\right)$, respiration rate $\left(\mathrm{ml} \cdot \mathrm{kg}^{-1} \cdot \mathrm{hr}^{-1}\right)$ and temperature $\left({ }^{0} \mathrm{C}\right)$ of different treatments

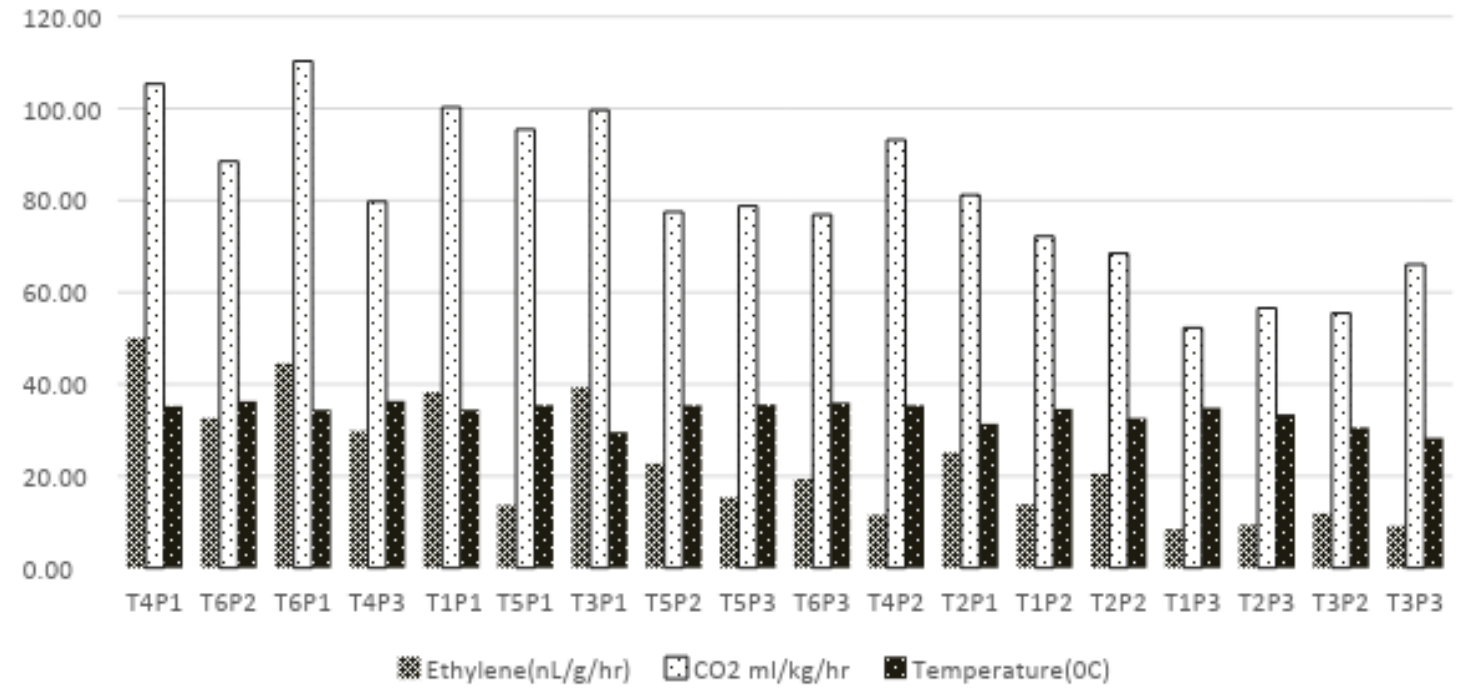

Fig.4(a-c) Relationships between shelf life and ethylene production, respiration rate and temperature
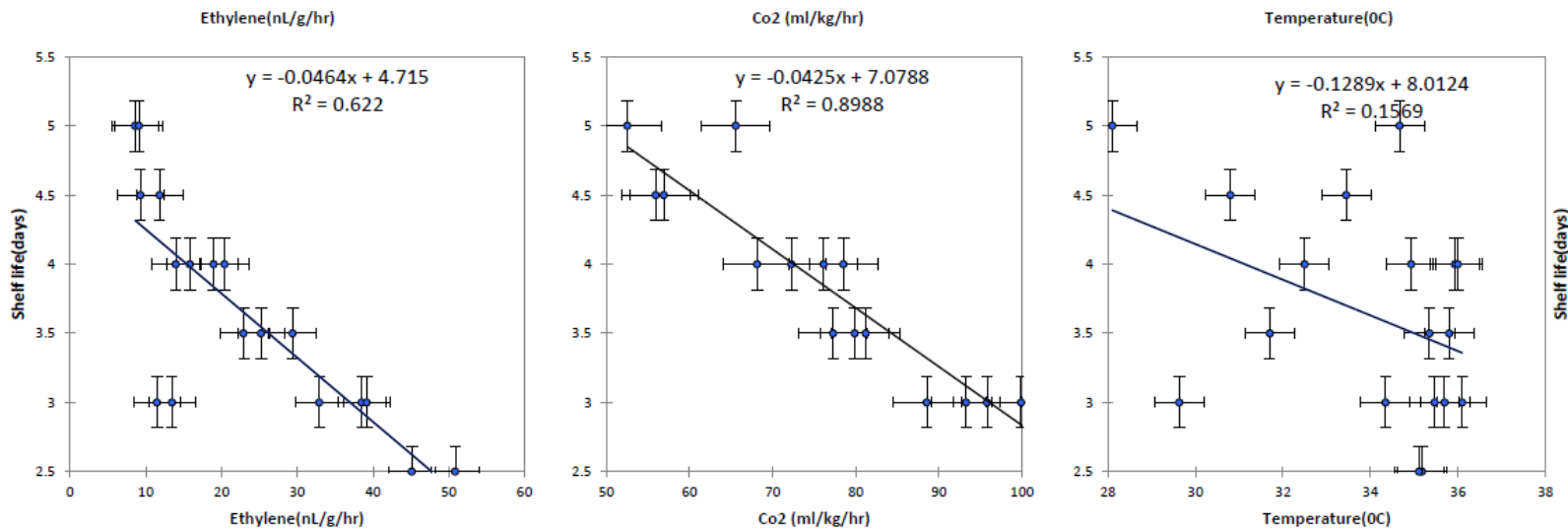

Finally, failure to develop high humidity under no packaging condition might be the reason for delay in $50 \%$ rotting, similar results was also reported by Piagentini et al., (2000).

The highest initial and final TSS $\left(4.5^{\circ} \mathrm{Bx}\right.$ and $\left.15.20^{\circ} \mathrm{Bx}\right)$ was observed in the treatment $\mathrm{T}_{6} \mathrm{P}_{1}$ where plans were treated with distilled water along with no packing condition and lowest values $\left(3.15^{\circ} \mathrm{Bx}\right.$ and $8.00^{\circ} \mathrm{Bx}$, respectively) were observed in the treatment $\mathrm{T}_{3} \mathrm{P}_{3}(0.005 \%$ Benzoic acid and LDPE packing) and $\mathrm{T}_{1} \mathrm{P}_{3}$
(0.3\% ascorbic acid and LDPE packing) respectively (Fig. 2).

Increase of total soluble solids (TSS) with no packing condition followed by newsprint and LDPE packaging regardless of chemical treatments might be due to the loss in moisture content which led to increased concentration of TSS and similar findings are supported the response (Goukh et al., 1995). However, the response observed did not corroborate with the findings Hussain et al., (2005). 
Retention of highest chlorophyll content (34.23 mg/g and $25.53 \mathrm{mg} / \mathrm{g}$ ) was observed in palak plants under the treatment of $0.3 \%$ ascorbic acid + no packing condition $\left(\mathrm{T}_{1} \mathrm{P}_{1}\right)$ and lowest values $(21.80 \mathrm{mg} / \mathrm{g}$ and $14.11 \mathrm{mg} / \mathrm{g}$, respectively) observed in $\mathrm{T}_{4} \mathrm{P}_{2}$ (Fig. 2) in this regard. Superior results from $\mathrm{T}_{1} \mathrm{P}_{1}(0.3 \%$ ascorbic acid and no packing) might be due to beet antioxidant property of ascorbic acid which prevented degradation of chloroplasts (Cadenas, 1985) and (Sies, 1985).

Sufficient availability of light in open condition might have played important role for stabilization and retention of chlorophyll than other packaging materials (i.e. Newsprint and Low Density Poly Ethylene).

Significantly highest ascorbic acid $(26.80 \mathrm{mg} / 100 \mathrm{~g})$ was recorded in $\mathrm{T}_{1} \mathrm{P}_{3}(0.3 \%$ ascorbic acid and LDPE packing). Whereas, the lowest $(22 \mathrm{mg} / 100 \mathrm{~g})$ observed in $\mathrm{T}_{6} \mathrm{P}_{1}$ (distilled water and no packaging) (Table 1). Analyzed results also revealed better retention of ascorbic acid with LDPE packing. The decrease in vitamin $\mathrm{C}$ content with storage duration can be attributed to the oxidation of ascorbic acid into dehydroascorbic acid by the enzyme ascorbic acid oxidase. Decrease in ascorbic acid content was found to be maximum with no packing condition than Low Density Poly Ethylene packing which might be due to insufficient level of oxygen in LDPE packing for oxidation of ascorbic acid. Similar findings reported in spinach beet (Mogren et al., 2012) and chard (Daiss et al., 2008).

\section{Estimation of ethylene production and respiration rate of Spinach beet}

\section{Ethylene $\left(\mathrm{C}_{2} \mathrm{H}_{4}\right)$ production rate}

The endogenous ethylene might have impacts on shelf life and quality of harvested vegetables (Porat et al., 2001). Initial ethylene production of the spinach beet was $7.40 \mathrm{nl}$. $\mathrm{g}^{-1} \cdot \mathrm{hr}^{-1}$ and at final consumption stage (shelf life) the production range was registered 8.41$50.03 \mathrm{nl} . \mathrm{g}^{-1} \cdot \mathrm{hr}^{-1}$ (Table 2). Significant reduction in ethylene release $\left(8.41 \mathrm{nl} . \mathrm{g}^{-1} \cdot \mathrm{hr}^{-1}\right)$ was observed in the treatment $\mathrm{T}_{1} \mathrm{P}_{3}(0.3 \%$ ascorbic acid and LDPE packing) followed by $\mathrm{T}_{3} \mathrm{P}_{3}\left(9.15 \mathrm{nl} \cdot \mathrm{g}^{-1} \cdot \mathrm{hr}^{-1}\right)$ and $\mathrm{T}_{2} \mathrm{P}_{3}\left(9.36 \mathrm{nl} . \mathrm{g}^{-1}\right.$. $\mathrm{hr}^{-1}$ ) (Table.2). Whereas, it was highest (50.03 $\left.\mathrm{nl} . \mathrm{g}^{-1} \cdot \mathrm{hr}^{-1}\right)$ in $\mathrm{T}_{4} \mathrm{P}_{1} \quad(0.5 \%$ Common salt+ no packing).

\section{Respiration rate}

Uneven respiration rate was identified in all the treatments. It was lowest (52.28 $\left.\mathrm{ml} . \mathrm{kg}^{-1} \cdot \mathrm{h}^{-1}\right)$ under $\mathrm{T}_{3} \mathrm{P}_{3}(0.3 \%$ ascorbic acid and LDPE packing) followed by $\mathrm{T}_{3} \mathrm{P}_{3}(55.46$ $\left.\mathrm{ml} . \mathrm{kg}^{-1} \cdot \mathrm{hr}^{-1}\right)$ and $\mathrm{T}_{2} \mathrm{P}_{3}\left(56.91 \mathrm{ml} \cdot \mathrm{kg}^{-1} \cdot \mathrm{hr}^{-1}\right)$. But, it was highest (110.34 ml. $\left.\mathrm{kg}^{-1} \cdot \mathrm{hr}^{-1}\right)$ under $\mathrm{T}_{6} \mathrm{P}_{1}$ (Distilled water + no packing) (Fig. 3). The variations in ethylene production might be due to storage temperature and relative humidity inside the packing condition (Wills et al., 1998). Production of endogenous ethylene increases cellular respiration, which in turn increases metabolic rate during storage and it was effected by packing condition (Mahajan and Goswani, 2001). These changes might be due to retention of more humidity in LDPE packing helped to reduce the respiration rate which automatically reduced ethylene production. Further, treatment of palak plants with $0.3 \%$ ascorbic acid might have deterrent effect on ethylene production and respiration rate respectively, due to their antioxidant property

\section{$\mathrm{O}_{2}$ consumption rate}

Lowest oxygen consumption rate (38.70ml. $\left.\mathrm{kg}^{-1} \cdot \mathrm{hr}^{-1}\right)$ was reviled in the treatment $\mathrm{T}_{1} \mathrm{P}_{3}(0.3 \%$ ascorbic acid + LDPE packing) followed by $\mathrm{T}_{3} \mathrm{P}_{2}$ (40.63 ml.kg $\left.{ }^{-1} \cdot \mathrm{hr}^{-1}\right)$ and $\mathrm{T}_{2} \mathrm{P}_{3}\left(41.44 \mathrm{ml} \cdot \mathrm{kg}^{-1} \cdot \mathrm{hr}^{-1}\right)$ and highest in this regard was observed in $\mathrm{T}_{6} \mathrm{P}_{1}$ 
$\left(80.20 \mathrm{ml} \cdot \mathrm{kg}^{-1} \cdot \mathrm{hr}^{-1}\right)$. During respiration process consumption of $\mathrm{O}_{2}$ shown similar behavior to that of release in $\mathrm{CO}_{2}$ (reparation rate), the loss of $\mathrm{O}_{2}$ and gain in the respiration rate will spoil the product quality due to the internal heat evolved from the tissues by the process of respiration.

\section{Temperature $\left({ }^{0} \mathrm{C}\right)$ and vital heat}

Production of temperature was varied among the treatments and its range was observed $28.29{ }^{0} \mathrm{C}$ to $36.34{ }^{0} \mathrm{C}$. Lowest temperature $\left(28.29^{\circ} \mathrm{C}\right)$ reviled in the treatment $\mathrm{T}_{3} \mathrm{P}_{3}$ ( $0.05 \%$ benzoic acid and LDPE packing) and highest in this regard was in $\mathrm{T}_{4} \mathrm{P}_{3}\left(36.34^{\circ} \mathrm{C}\right)$. Among all the treatments lowest vital heat 3314.15 Kcal.Ton. ${ }^{-1} .24$ hrs $^{-1}$ was observed $\mathrm{T}_{1} \mathrm{P}_{3}(0.3 \%$ ascorbic acid + LDPE Packing) followed by $\mathrm{T}_{3} \mathrm{P}_{2} \quad\left(3422.40\right.$ Kcal.Ton. ${ }^{-1} .24$ $\mathrm{hrs}^{-1}$ ) and highest in this regard 6766.88 Kcal.Ton. ${ }^{-1} .24 \mathrm{hrs}^{-1}$ was observed in $\mathrm{T}_{6} \mathrm{P}_{1}$ (Distilled water+ No packing) condition. Production of highest temperature and vital heat under LDPE and newsprint packing condition might be due to rise in respiration rate inside the packing condition will increase the internal temperature.

Relationships between shelf life and ethylene production, respiration rate and temperature

Regression analysis to reveal the relations between the two variables, i.e., ethylene production $\left(\mathrm{nL}^{-1} \cdot \mathrm{g}^{-1} \cdot \mathrm{hr}\right)$ and shelf life (days) indicated a linear relation as well as a highly significant $(\mathrm{P} \leq 0.01)$ correlation coefficient $(\mathrm{r}=0.62$, P-value $<0.01)$. Besides, $\mathrm{R}^{2}$ (coefficient of determination), revealed that it was possible to account up to $63 \%$ of the variability in shelf life (y), to ethylene production. The relationship between ethylene production and shelf life was negative and followed the linear equation: of $Y=4.715$ $0.0464 x$, representing a high negative value of coefficient of regression (b), which means shelf life decrease against increased ethylene production (Fig. 4 a-c). Also, analysis of regression indicated that a best described response as a linear regression for respiration rate (Respiration rate production) and shelf life $\left(\right.$ respiration rate $=7.07-0.042 \mathrm{x}, \mathrm{R}^{2}=$ 89.88; $\mathrm{p} \leq 0.01$ ), (Fig. 4a-c). The relationship between internal temperature and shelf life was negative and followed the linear equation: of $\mathrm{Y}=8.01-0.12 \mathrm{x}$, representing a negative value of coefficient of regression (b), which means shelf life decrease against increased internal temperature (Fig. 4a-c). Significant linear relationship between shelf life, ethylene production, respiration rate and temperature provides the clue that shelf life was depending on all these traits. Linear regression equations for shelf life suggested that increase in one unit $\left(10 \mathrm{nl} \cdot \mathrm{g}^{-1} \cdot \mathrm{hr}^{-1}\right.$, $10 \mathrm{ml} . \mathrm{kg}^{-1} \cdot \mathrm{hr}^{-1}, 2^{0} \mathrm{C}$ ) of ethylene content, Respiration rate production and temperature lead to decreased shelf life by 0.04 days, 0.04 days and 0.12 days respectively. From the above mentioned results, it could be concluded that the coefficients of determination $\left(\mathrm{R}^{2}\right)$ of 0.89 and 0.62 indicated that the shelf life involved in this study affected the total variability of ethylene production and respiration rate by $63 \%$ and $89 \%$, respectively and the temperature indicated less (15\%) impact.

It was observed that treatment with $0.3 \%$ ascorbic acid and LDPE packing helps to reduce the physiological loss in weight, ethylene production rate and helps to increase shelf life of spinach beet during storage

\section{References}

Abu-Goukh, A.A., Mofadal, H.I. and AbuSarra, A.F. 2001. Post-harvest quality and storability of twenty onion cultivars at 'Jabal Marra' area-Sudan. University 
of Khartoum Journal of Agricultural Sciences, 9 (2): 236-253.

Attia, M.M. 1995. Effect of postharvest treatments on fruit losses and keeping quality of Balady oranges through cold storage. Alex journal of Agriculture Research.40 (3):349.

Brandl, M. T., and R. E. Mandrell. 2002. Fitness of Salmonella enterica serovar Thompson in the cilantro phyllosphere Applied Environmental Micro Biology 68:3614-3621

Burton W G. 1978. Biochemical and physiological effects of modified atmospheres and their role in quality maintenance', in: Hultin $\mathrm{H} \mathrm{O}$ and Milner M (Eds.), Postharvest Biology and Biotechnology, FNP, Westport CT, 1978

Daiss, N., Lobo, M.G. and Gonzalez, M.2008. Journal of food science. 73 (6): S314.Wills, R., W.B. McGlasson, D. Graham, and D. Joyce. 1998. Postharvest: An introduction to the physiology and handling of fruit, vegetables and ornamentals, p. 262. $4^{\text {th }}$ Edition. Commonwealth Agricultural Bureaux International (CABI), Wallingford, UK.

Hussian, I., Sabeen, N. G., Muhammed, R. K., Khan, T.M. and Iftikhar, S. 2005.Varietal suitability and storage stability of mango squash. International journal of Agriculture and Biology, 7:1038-1039.

Mahajan PV, Oliveira FAR, Montanez JC, Frias J. 2007. Development of userfriendly software for design of modified atmosphere packaging for fresh and fresh-cut produce. Innovative Food Science Emerging Technology. 8: 8492.

Majeski, E. and C. A. Beasley, 1968. New chemical aid to fight regreening passes its early tests. West. Fruit Grow 22 (11): 22-23.

Mogren, L., Reade, J., Monaghan, J. 2012: Effects of environmental stress on ascorbic acid content in baby leaf spinac (Spinacia oleracea). - Acta Hort. (ISHS) 939:205-208.

Nyaura J.A., Sila D.N., Owino W.O. 2014. Postharvest stability of vegetable amaranth (Amaranthus dubius) combined low temperature and modified atmospheric packaging. Food Science and Quality Management 30:66-72

Piagentini, A.M., Guides, D.R. and Pirovani, M.E.2000.Hygiene Aliment.14 (74):32.

Porat, R., Feng X., Huberman M., Galili D., Goren R., Goldschmidt E.E. 2001. Gibberellic acid slows postharvest degreening of 'Oroblanco' citrus fruits. HortScience 36, 937-940

Prasad, B. V. G., Chakravorty, S. and Deb, P. 2014. Effect of different post-harvest treatments, packaging and storage condition on French bean (Phaseolus vulgaris L.). HortFlora Res. Spectrum 3 (2):150-153

Sies, H., Cadenas, E. 1985. Oxidative stress Dam- age to intact cells and organs. Philosophical Transactions of the Royal Society of Lond. Biological Sciences, 311:617-631. doi:10.1098/rstb.1985 0168 .

\section{How to cite this article:}

Prasad, B.V.G., S. Chakravorty, P. Ganagadhara Rao and Deb, P. 2018. Effect of Post-harvest Treatments and Packaging on Spinach Beet (Beta vulgaris var bengalensis Hort.) under Ambient Condition. Int.J.Curr.Microbiol.App.Sci. 7(11): 711-720.

doi: https://doi.org/10.20546/ijcmas.2018.711.085 